\title{
Synthesis, microstructural analysis and mechanical properties of alumina-matrix cermets
}

\author{
José G. MIRANDA-HERNÁNDEZ - Departamento de Materiales, Universidad Autónoma \\ Metropolitana \\ Sebastián DÍAZ DE LA TORRE - CIITEC-IPN, Cerrada de Cecati S/N \\ ENRIQUE ROCHA-RANGEL - Departamento de Ingeniería Metalúrgica • nrqrocha@gmail.com \\ Received: 11.06.2009. • Érkezett: 2009.06.11. http://dx.doi.org/10.14382/epitoanyag-jsbcm.2010.1
}

\begin{abstract}
$\mathrm{Al}_{2} \mathrm{O}_{3}$ matrix cermets have been produced from mechanically mixed powders containing different metals (Al, Fe or Ti) as reinforcements. The powder mixture was compacted to cylindrical samples, which were subjected to pressure-less sintering $1500^{\circ} \mathrm{C}$ for $1 \mathrm{~h}$. Microstructure of the sintered bodies was studied by optical and electron microscopy. It was found that microstructure of cermets with $\mathrm{Al}$ and $\mathrm{Fe}$ consisted of equally distributed metallic particles in the $\mathrm{Al}_{2} \mathrm{O}_{3}$ matrix. However, cermets with Ti reinforcement were characterized by a metallic network interconnected with the matrix material. The relative densities of the Al-, Fe- and Ti-containing cermets in order were 93\%, 93.5\% and $87.3 \%$, respectively. These densities and the microstructure of particular cermets most probably make possible to produce composites with small elastic modulus and improved fracture toughness. It was concluded that incorporation of a ductile metal into a hard ceramic matrix improves its fracture toughness.
\end{abstract}

The probable toughening mechanism is crack bridging due to the homogeneous distribution of ductile metal in the microstructure of cermets.

Keywords: $\mathrm{Al}_{2} \mathrm{O}_{3}-\mathrm{Al}_{1} \mathrm{Al}_{2} \mathrm{O}_{3}-\mathrm{Ti}_{1} \mathrm{Al}_{2} \mathrm{O}_{3}-\mathrm{Fe}$, cermets, metallic network

\section{Introduction}

Alumina-based ceramics $\left(\mathrm{Al}_{2} \mathrm{O}_{3}\right)$ possess excellent physical and chemical properties, as well as good mechanical resistance and thermal stability [1]. Nevertheless, their applications are some limited since they present high fragility; it is to say, they are not deformed easily under the action of a load due to their high values of Young's module. Because of this particularity $\mathrm{Al}_{2} \mathrm{O}_{3}$ ceramics are very sensitive to minimal defects in their microstructure, which acts as point of beginning of cracks $[2,3]$. In consequence the trend of obtaining new materials with combinations of properties between ceramic and metals with good mechanical resistance, together with improved fracture toughness, has done the develop of new materials systems ceramic-based, reinforced with metallic particles and in addition fabricated by emergent methods of processing. In some recent studies there has been demonstrated that ceramic materials can improve their fracture toughness by means of the homogeneous incorporation of fine particles in their matrix of ductile metals. As example of them, they have been reported the production by diverse methods and with different reinforcement metal amounts of $\mathrm{Al}_{2} \mathrm{O}_{3} / \mathrm{Al}$ [4], $\mathrm{Al}_{2} \mathrm{O}_{3} / \mathrm{Cr}$ [5], $\mathrm{Al}_{2} \mathrm{O}_{3} / \mathrm{Cu}$ [6], $\mathrm{Al}_{2} \mathrm{O}_{3} / \mathrm{Ni}$ [7], $\mathrm{Al}_{2} \mathrm{O}_{3} / \mathrm{Mo}[8], \mathrm{Al}_{2} \mathrm{O}_{3} / \mathrm{Ti}$ aluminide [9] and $\mathrm{Al}_{2} \mathrm{O}_{3} / \mathrm{Ni}_{3} \mathrm{Al}$ [10]. Some of these composites were synthesized by powders' techniques, which departs from a mixture of powders from a high energy mechanical grinding, and later are submitted to a pressing process, and finally they are sintered to certain time and temperature giving the desired composite material, that in comparison with the material base, this one experiences a decrease in their hardness and elasticity module, while, his fracture toughness increases, factors that in a general way favor the fact that the new composite tolerates better the generation and growth of cracks when this one is working under the action of loads.
José G. MIRANDA-HERNÁNDEZ

actually is enrolled at the doctor's program in Materials Science and Engineering of the Metropolitan Autonomous University in Mexico City. In this same university he has studied his master and bachelor degrees in the fields of materials science and physical engineering respectively. His main field of work is the study of ceramic materials reinforced with metals, from where he has written several works.

Enrique ROCHA-RANGEL actually is titular professor at the Metallurgy Engineering Department of the National Institute Politechnique (IPN) in Mexico City. He has gotten his bachelor and master in Metallurgical Engineering by the IPN. His doctoral was in the field of Metallurgy and Materials in the IPN. He also had research stay and postdoctoral studies in the Toyohashi University of Technology, Japan and Oak Ridge National Laboratory, USA respectively. His main field of work is the study of composite materials reinforced with different metals, ceramics and polymers, from where he has written several works.

Sebastián DÍAZ DE LA TORRE actually is titular professor in the Research and Innovation Technology Center of the IPN. His bachelor studies were in the field of the Chemistry Engineering by the Autonomous Zacatecas University in México. He has gotten his master degree in Metallurgical Engineering by the IPN. Whereas, his doctoral studies were in the field of the Materials Processing in the Kyoto University, Japan. He had worked for more than 10 years as an invited researcher in the Technological Research Institute of Osaka, Japan. His main field of work is in the referent to production and characterization of structural materials, from where he has written several works.

\section{Experimental}

The raw materials are powders of $\mathrm{Al}_{2} \mathrm{O}_{3}(99.9 \%, 1 \mu \mathrm{m}$, Sigma, USA) and $\mathrm{Al}, \mathrm{Fe}$ and $\mathrm{Ti}$ in powder (99.9\% purity, $1-2 \mu \mathrm{m}$, Aldrich, USA). The amount of powders used is that one that allows at the end of the processing the obtaining of the next cermets; $\mathrm{Al}_{2} \mathrm{O}_{3}-10$ vol.\% $\mathrm{Al}, \mathrm{Al}_{2} \mathrm{O}_{3}-10$ vol.\% Ti and $\mathrm{Al}_{2} \mathrm{O}_{3}-10$ vol.\% $\mathrm{Fe}$, which from now on it, will be called $\mathrm{C} 1, \mathrm{C} 2$ and $\mathrm{C} 3$ cermets respectively. The powders are submitted to mixinggrinding process with the help of a horizontal mill that is working a speed of rotation of $300 \mathrm{rpm}$ during $12 \mathrm{~h}$ and using as elements of grinding balls of $\mathrm{ZrO}_{2}$ stabilized with $\mathrm{Y}_{2} \mathrm{O}_{3}$, the ratio balls weight/powder weight is of 25:1. With the obtained powders' mixture, they are fabricated cylindrical samples with dimensions of $20 \mathrm{~mm}$ in diameter and $3 \mathrm{~mm}$ in thickness; this is made by uniaxial pressing in cold using $200 \mathrm{MPa}$. Then the compacted samples are pressureless sintered at $1500^{\circ} \mathrm{C}$ during $1 \mathrm{~h}$ using a nitrogen atmosphere inside the furnace. The speeds of warming and cooling are kept constant and equal to $10^{\circ} \mathrm{C} / \mathrm{min}$. The characterization of the synthesized products is carried out of the following way; Sample's density is evaluated by Arquimedes' method. The hardness is measured with the help of Vickers equipment. The fracture toughness is determined by the indentation fracture method using Evans's equation [11]. The elastic module of the materials is valued by ultrasound technologies. The microstructure of the composites 
is observed with help of a scanning electron microscope (SEM) and an optical microscope (OM). The SEM is equipped with a detector of energy dispersive of X-ray (EDX) with which the constituents present in the microstructure could be identified.

\section{Results and discussion}

In Table 1. they are reported the results of the densities measurements of samples in green, sintered, theoretical and the relative densification for $\mathrm{C} 1, \mathrm{C} 2$ and $\mathrm{C} 3$ cermets. In this table, the density in green obtained for the three different composites is very similar, this particularity is attributed to that composites, were made under the same conditions of load-weight relation. After sintered materials at $1500^{\circ} \mathrm{C}$ during $1 \mathrm{~h}$, the material that reaches the best densification is the cermet that contains $\mathrm{Ti}$, who obtained a relative densification of $93.5 \%$, followed by the one that contains $\mathrm{Al}$ with $93 \%$ and finally the cermet that contains Fe with only $87.3 \%$ of its relative density. The reason of obtaining differences in the densification depends on the thermal properties and densities of the different used metals. In consequence the mass transfer phenomenon happens in a different way, depending of the metal that reinforces the ceramic one. The cermet that contains Al should have been sintered with the formation of a liquid phase, since the sintered temperature is higher than $660^{\circ} \mathrm{C}$ that corresponds to the melting point of this metal. Whereas, the two other cermets were consolidated via solid sintering. Density of $\mathrm{Al}\left(2.7 \mathrm{~g} / \mathrm{cm}^{3}\right)$ and principally density of $\mathrm{Ti}\left(4.5 \mathrm{~g} / \mathrm{cm}^{3}\right)$ are similar to density of alumina $\left(4 \mathrm{~g} / \mathrm{cm}^{3}\right)$, in this sense they are a good homogenization of metallic particles during and after milling so this maintain good contacts between ceramic and metallic particles helping in a good diffusion during the sintering process. On the other hand, Fe has a very high density $\left(7.86 \mathrm{~g} / \mathrm{cm}^{3}\right)$ in comparison with alumina, so this causes that they are not many contacts between ceramic and metallic particles after milling and consequently during sintering and for that reason densification of this cermet is very poor.

\begin{tabular}{lccc} 
Cermet & $\mathbf{A l}_{2} \mathbf{O}_{3}-\mathbf{- 1 0} \% \mathbf{A l}$ & $\mathbf{A l}_{2} \mathbf{O}_{\mathbf{3}}-\mathbf{1 0} \% \mathbf{~ T i}$ & $\mathbf{A l}_{2} \mathbf{O}_{3}-\mathbf{1 0} \% \mathbf{~ F e}$ \\
Green density $\left(\mathrm{g} / \mathrm{cm}^{3}\right)$ & 1.56 & 1.57 & 1.56 \\
\hline $\begin{array}{l}\text { Experimental density } \\
\left(\mathrm{g} / \mathrm{cm}^{3}\right)\end{array}$ & 3.61 & 3.79 & 3.83 \\
\hline $\begin{array}{l}\text { Theoretical density } \\
\left(\mathrm{g} / \mathrm{cm}^{3}\right)\end{array}$ & 3.87 & 4.05 & 4.39 \\
\hline Relative density $(\%)$ & 93.00 & 93.50 & 87.30 \\
\hline
\end{tabular}

Table 1. Densities of different cermets

1. táblázat Az elöállított különböző fémkerámiák sürüség értékei

\section{Microstructure}

The microstructure observed by optical microscope correspondent to $\mathrm{Al}_{2} \mathrm{O}_{3}-10$ vol. $\% \mathrm{Al}$ and $\mathrm{Al}_{2} \mathrm{O}_{3}-10$ vol.\% $\mathrm{Fe}$ cermets is showed in Figures $1 \mathrm{a}$ and $1 \mathrm{~b}$ respectively, in both cases the ceramic matrix is identified by an opaque phase, whereas, the clear and brightness phase corresponds to the distribution of the metallic particles in the matrix. The microstructure for $\mathrm{C} 1$ and $\mathrm{C} 3$ cermets is similar, though, for the $\mathrm{C} 3$ cermet the size of particle is coarser in comparison with the particles in $\mathrm{C} 1$ cermet that presents a good distribution of small particles in the matrix of the composite. This can owe to the high values of density of the Fe compared with that of the alumina, that provoke its segregation towards certain zones of the matrix, besides the generation of cracks and pores in the cermet. The microstructure observed in Figure 1c corresponds to $\mathrm{C} 2$ cermet, in this figure it is appreciated a metallic network finely distributed in the ceramic matrix. Though the Ti did not melt, this one receives the sufficient energy to be able to move inside the compound and form the metallic network and of there the observed microstructure in the composite.

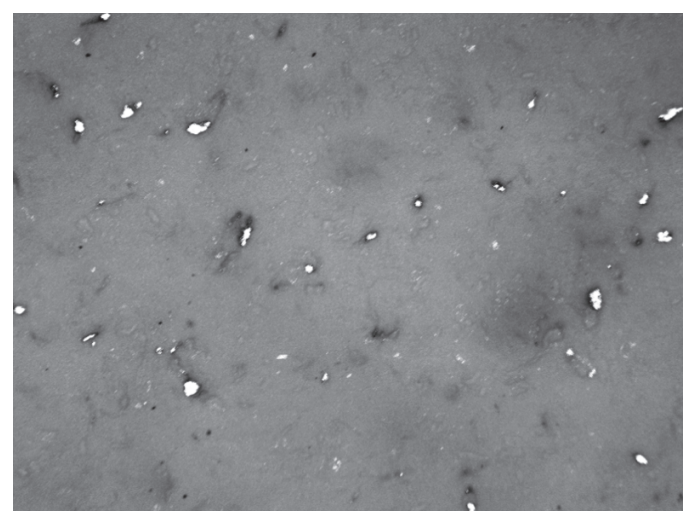

a) C1 cermet

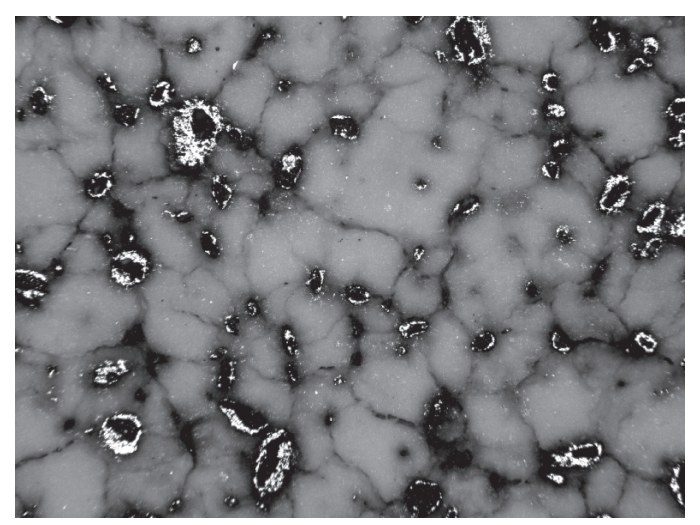

b) C3 cermet

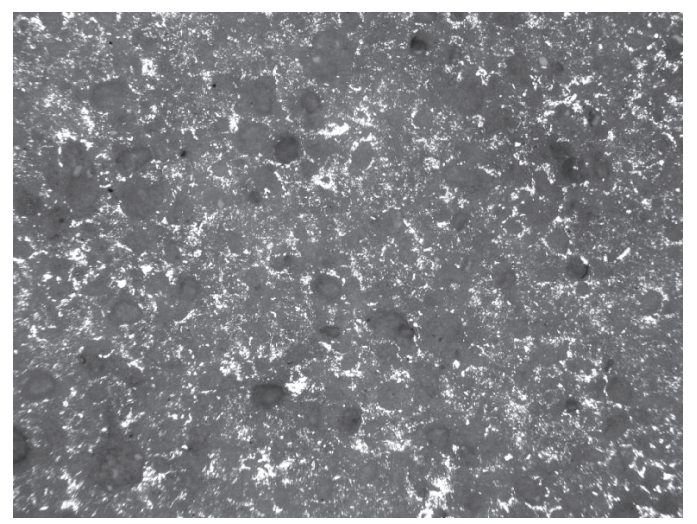

c) C2 cermet

Fig. 1. Microstructure pictures taken with optical microscope (50X) 1. ábra A mikroszerkezet optikai mikroszkópos felvételei (50x) 
Scanning electron microscopy (SEM). Looking Figure 2a that shows the microstructure of the $\mathrm{C} 1$ cermet it can be seen that the microstructure is formed by small and uniform grains, without stopping observing any big grains. With help of the EDX analysis it was determined that the gray phase corresponds to the $\mathrm{Al}_{2} \mathrm{O}_{3}$ ceramic matrix, though that the metallic particles here are not observed. A good densification is present in the composite, considering in addition the homogeneous distribution of the metallic particles that are visible in optical microscope, which also is tied to the presence of a minimal distribution of pores (black zones) apparently small. The grain's size of the matrix is in average about $4 \mu \mathrm{m}$, though they managed to observe bigger grains. In Figure $2 b$ it is possible to observe the microstructure of the $\mathrm{C} 2$ cermet, here it observed a material with a thin and homogeneous microstructure, with a good distribution of the metallic particles (clear phase) in the matrix, same that were identified as Ti by the EDX analysis. The grain's size of both phases is changed, in average for the grains of the matrix ranges between $3 \mu \mathrm{m}$ and $10 \mu \mathrm{m}$, whereas, for the metallic particles it is of approximately $4 \mu \mathrm{m}$. Finally the microstructure of the $\mathrm{C} 3$ cermet appears in Figure $3 \mathrm{c}$, in this figure seemingly there is no presence of metallic particles in the material since the microstructure is constituted principally by an opaque phase that corresponds to the ceramic matrix according to the EDX analysis. This owes practically to that the metallic particles during the sintered were segregated to certain zones of the material increasing this way their size; consequently their distribution in the matrix diminishes. As for the densification it refers, is observed that there is presence of pores of different size, this brings as consequence a decrease in the density of the compound. Likewise, is observed a homogeneous size of grain of the ceramic one.

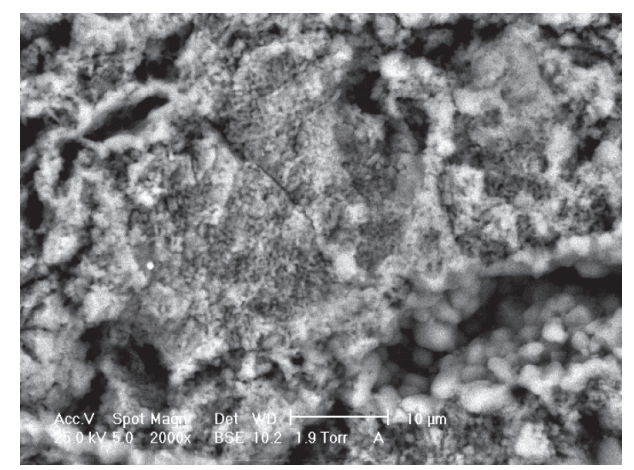

a) $C 1$ cermet

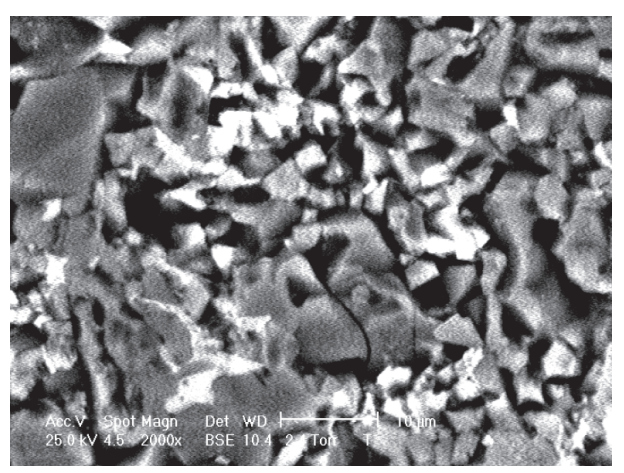

b) C2 cermet

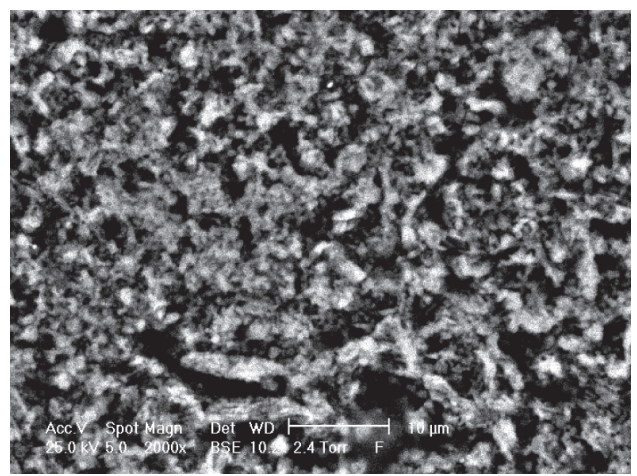

c) $C 3$ cermet

Fig. 2. Microstructure pictures taken with scanning electron microscope

2. ábra A mikroszerkezet pásztázó elektronmikroszkópos felvételei

In Figure 3 it is presented the microstructure of the $\mathrm{C} 2$ cermet taken with the help of SEM at low magnifications, here there is clearer the formation of a thin metallic network (clear and brightness phase) formed by the Ti used as reinforcement of the ceramic. This network surrounds well some of the matrix grains. In a general way there is the presence of a cermet with a thin and homogeneous microstructure constituted by a metallic semi-constant network interpenetrated with the ceramic matrix.

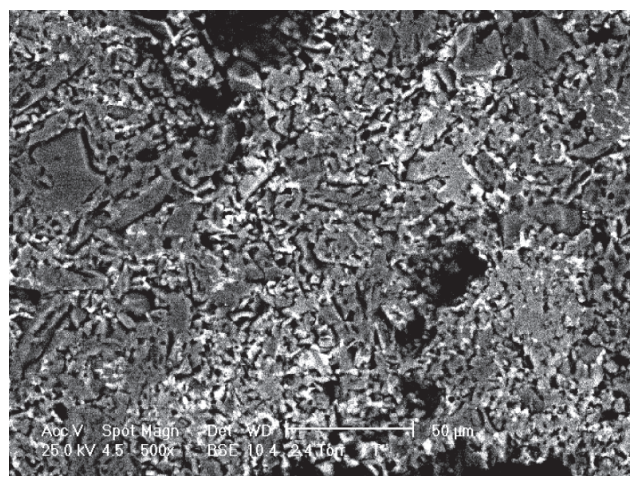

Fig. 3. Metallic network formed by titanium in the ceramic matrix 3. ábra Titán fémszövedék a kerámia mátrixban

\section{Mechanical properties}

The Table 2. shows the values of microhardness, Young's module and fracture toughness as a function of the metallic element used as reinforcement of the ceramic matrix. It is observed that the $\mathrm{C} 2$ cermet is that of major hardness followed by $\mathrm{C} 3$ and $\mathrm{C} 1$ cermets respectively, this makes think that the ceramic matrix diminishes her hardness in combination of these metals and that it depends not only on the percentage of the present metal in the composition, if not, also of the hardness of each metal, it means, the hardness of $\mathrm{Ti}$ is major that of the $\mathrm{Fe}$ and $\mathrm{Al}$ respectively, and this way is made notice in the cermets. The fact that the hardness of the matrix diminishes in presence of a metal it is an indication of which the elastic module meets affected. Considering that the elastic module, it a measurement of the resistance of the material to the elastic deformation. Also from Table 2 it can be observed that in all cases the fracture toughness of monolithic $\mathrm{Al}_{2} \mathrm{O}_{3}$ was improved, principally in 
cermets reinforced with Ti. In general the incorporation of metals in the ceramic matrix enhances the fracture toughness due to plastic deformation of the metallic phase, which forms crack-bridging ligaments when a crack is growing in the material under a tensile stress action. In other words, energy absorbed for plastic deformation makes energy unavailable for crack extension. Additionally, the deformed particles could bridge the faces of the crack wake. Thereby exerting closure stresses, reducing the effect on the stress intensity at the crack tip $[12,13]$. For the case of $\mathrm{Al}_{2} \mathrm{O}_{3} / \mathrm{Ti}$ system: because titanium and alumina densities are very similar, $\mathrm{Ti}$ is well dispersed in alumina matrix, forming a good and homogeneity interface in the composite microstructure that promotes diffusion and densification, as a consequence good toughening of the final material.

\begin{tabular}{lccc} 
Composite & $\begin{array}{c}\text { Microhardness } \\
(\mathbf{G P a})\end{array}$ & $\begin{array}{c}\text { Young's module } \\
(\mathbf{G P a})\end{array}$ & $\begin{array}{c}\mathbf{K}_{\mathbf{c}} \\
\left(\mathrm{MPa} \cdot \mathbf{m}^{-1 / 2}\right)\end{array}$ \\
\hline $\mathrm{Al}_{2} \mathrm{O}_{3}$ & $20.97+/-1.7$ & 257.00 & $3.2+/-0.2$ \\
\hline $\mathrm{Al}_{2} \mathrm{O}_{3}-10 \% \mathrm{Al}$ & $18.62+/-1.3$ & 73.98 & $4.1+/-0.1$ \\
\hline $\mathrm{Al}_{2} \mathrm{O}_{3}-10 \% \mathrm{Fe}$ & $18.51+/-1.5$ & 50.17 & $3.7+/-0.1$ \\
\hline $\mathrm{Al}_{2} \mathrm{O}_{3}-10 \% \mathrm{Ti}$ & $18.17+/-1.5$ & 22.88 & $4.8+/-0.1$ \\
\hline
\end{tabular}

Table 2. Mechanical properties values of different cermets fabricated 2. táblázat Az elóállított különböző fémkerámiák mechanikai tulajdonságai

\section{Conclusions}

Different $\mathrm{Al}_{2} \mathrm{O}_{3}$-based composites reinforced with metallic particles (Al, Fe or $\mathrm{Ti}$ ) were fabricated successfully through the combination of mechanical milling and sintering.

The degree of final densification in the cermets depends strongly on the reinforcement metal used in the same ones, since the thermal properties and density of this one influence the phenomena of diffusion. The cermet with better densification after sintering is the one that contains Ti reaching a densification of $93.5 \%$ of its theoretical density, followed by that one that contains $\mathrm{Al}$ with $93 \%$ and finally the cermet that contains Fe with $87.3 \%$ of relative density.

The obtained microstructure corresponds to a homogeneous distribution of metallic particles for the case of the $\mathrm{Al}_{2} \mathrm{O}_{3}$ $10 \% \mathrm{Al}$ cermet. The microstructure of the $\mathrm{Al}_{2} \mathrm{O}_{3}-10 \% \mathrm{Fe}$ cermet is very heterogeneous due to the segregation of the Fe during the sintering, which owes to the high value of the density of the Fe in comparison with that of the alumina. The microstructure of the $\mathrm{Al}_{2} \mathrm{O}_{3}-10 \%$ Ti cermet presents a metallic semi-constant network formed by the titanium, same that meets interpenetrated with the ceramic matrix.

From the fracture toughness measurements and microstructure observations, it can be commented that the toughening mechanism in $\mathrm{Al}_{2} \mathrm{O}_{3} /$ metal reinforced cermets is due to crack bridging.

\section{Acknowledgment}

Authors would thank Universidad Autónoma Metropolitana for technical and financial support from 2260235 project and ESIQIE-IPN for technical support.

\section{References}

[1] Miranda, J.G.: Efecto del contenido de Cu en las propiedades mecánicas y resistencia eléctrica de un material compuesto base $\mathrm{Al}_{2} \mathrm{O}_{3}$, Master Thesis, UAM-A, Mexico, 2006.

[2] Rebolledo, C.P. - Jiménez, R.: Ciencia de Materiales Teoría-Ensayos-Tratamiento, Ediciones Pirámide, Spain, 1993.

[3] Meza, J.: Tenacidad a la Fractura en Cerámicos, Master Thesis, Universidad Nacional de Medellín, Colombia, 2001.

[4] Konopka, K. - Szafran, M.: Fabrication of $\mathrm{Al}_{2} \mathrm{O}_{3}-\mathrm{Al}$ Composites by Infiltration Method and Their Characteristics, J. Mater. Proc. Technol., 175, (2006), pp 266-270.

[5] Marci, C. - Katarzyna, P.: Processing, Microstructure and Mechanical Properties of $\mathrm{Al}_{2} \mathrm{O}_{3}-\mathrm{Cr}$ Nanocomposites, J. Eur. Ceram. Soc., 27, (2007), pp. 1273-1279.

[6] Miranda Hernández J.G. - Soto Guzmán, A.B. - Rocha-Rangel, E.: Production and Characterization of $\mathrm{Al}_{2} \mathrm{O}_{3}-\mathrm{Cu}$ Composite Materials, J. Ceram. Proc. Res., 7, (2006), pp. 311-314.

[7] Lieberthal, M.I. - Kaplan, W.: Processing and Properties of $\mathrm{Al}_{2} \mathrm{O}_{3}$ Nanocomposites Reinforced with Sub-Micron Ni and $\mathrm{Ni}_{2} \mathrm{O}_{4}$, Mater. Sci. Eng., A302, (2001), pp. 83-91.

[8] Lucchini, E - Casto, S. - Sbaizero, O.: The Performance of Molybdenum Toughened Alumina Cutting Tools in Turning a Particulate Metal Matrix Composite, Mater. Sci. Eng., A357, (2003), pp. 103-106.

[9] Travirskya, N. - Gotmanb, I. - Claussen, N.: Alumina-Ti Aluminide Interpenetrating Composites: Microstructure and Mechanical Properties, Mater. Lett., 57, (2003), pp. 3422-3426.

[10] Sglavo, V.M - Marinob, F. - Zhang, B.R. - Gialanella, S.: Ni ${ }_{3} \mathrm{Al}$ Intermetallic Compound as Second Phase in $\mathrm{Al}_{2} \mathrm{O}_{3}$ Ceramic Composite, Mater. Sci. Eng., A239-240, (1997), pp. 665-671.

[11] Evans, A.G. - Charles. E.A.: Fracture toughness determination by indentation, J. Am. Ceram. Soc., Vol.59, (1976), pp. 371-372.

[12] Ji, Y. - Yeomans, J.: Processing and Mechanical Properties of $\mathrm{Al}_{2} \mathrm{O}_{3}-5$ vol. \% Cr Nanocomposites, J. Eur. Ceram. Soc., 22, (2002), pp. 1927-1936.

[13] Lalande, J. - Scheppokat, S. - Jansen, R. - Claussen, N.: Toughening of Alumina/Zirconia Ceramic Composites with Silver Particles, J. Eur. Ceram. Soc., 22, (2002), pp. 2165-2171.

Alumínium-oxid mátrixú fémkerámiák szintézise, mikroszerkezetének elemzése és mechanikai tulajdonságai Porkohászati úton szintetizáltunk alumínium-oxid mátrixú fémkerámiákat különbözô szilárdságnövelô fémekkel (AI, Fe vagy Ti). A fémkerámiák készítéséhez száraz mechanikus porkeverékeket használtunk. A porkeverékekból henger alakú próbatesteket préseltünk, melyeket nyomás nélkül, $1500^{\circ} \mathrm{C}$ hômérsékleten 1 órán át szintereltünk. Az így elôállított anyagok mikroszerkezetét optikai- és elektronmikroszkóppal vizsgáltuk. A megfigyelések alapján a fémkerámiák egy $\mathrm{Al}_{2} \mathrm{O}_{3}$ kerámiai mátrixból állnak, a fém alumíniumot és vasat tartalmazó fémkerámiák esetében a fémrészecskék ebben a mátrixban vannak elszórva. A fém titánt tartalmazó fémkerámiák esetében viszont egy a kerámia mátrixszal összefonódó fémszövedék figyelhetô meg. Az Al, Fe és Ti tartalmú fémkerámia próbatestek relatív súrūsége megfelelōen 93\%, 93,5\% és $87,3 \%$ volt. Ez a súrūség, a fémkerámiák mikroszerkezetével egyetemben, lehetôvé teszi kis rugalmassági modulusú, megnövelt szakítószilárdságú kompozit anyagok előállítását. Ebben az értelemben kijelenthetô, hogy egy nyújtható fémnek a szilárd kerámiai mátrixszal való elegyítése a mátrix szivósságának növeléséhez vezet. A szívósság növelésének mechanizmusa valószínúleg azon alapszik, hogy a jelenlévō, finoman eloszlatott fém mintegy „áthidalja” a fémkerámia mikrorepedéseit.

Kulcsszavak: $\mathrm{Al}_{2} \mathrm{O}_{3}-\mathrm{Al}, \mathrm{Al}_{2} \mathrm{O}_{3}-\mathrm{Ti}, \mathrm{Al}_{2} \mathrm{O}_{3}-\mathrm{Fe}$, fémkerámiák, fémszövedék 